\title{
COMPETITIVE EFFECTS OF HERBACEOUS SPECIES ON WATER POTENTIAL AND GROWTH OF QUERCUS ITHABURENSIS SSP. MACROLEPIS SEEDLINGS
}

\author{
A. PANTERA ${ }^{1 *}$ \\ V.P. PAPANASTASIS ${ }^{2}$
}

\author{
${ }^{1}$ TEI Lamias, Department of Forestry, \\ and Natural Environment Management \\ 36100, Karpenisi, Greece \\ ${ }^{2}$ Aristotle University of Thessaloniki, \\ Forestry Department, 541 24, Thessaloniki, Greece
}

Received: 25/09/11

Accepted: 28/12/11

\section{ABSTRACT}

A noticeable decline of Quercus ithaburensis ssp. Macrolepis, a typical mediterranean species, has been recorded in the past few decades throughout Greece. The triggers were mostly human influences and specifically illegal cuttings, wildfires, and overgrazing. Regeneration and future management of this species is therefore questionable. To investigate the effect of companion plants on this decline as expressed by water availability and plant growth, a pot experiment was conducted and oak seedlings were planted with Bromus sterilis and a mixture of Trifolium repens and $T$. fragiferum as companion plants. Midday water potential from May to September and oak growth at the end of the experiment were measured as factors affecting oak physiology. The results suggest a different effect on the water potential of the oak seedlings depending on the companion plant species and the time of the year. The presence of a companion plant that has completed its life cycle by the end of spring may positively influence the water status of oaks during the summer months due to shading and lower soil water evaporation. On the contrary, when the companion plants continue their life cycle in the summer, the negative effect may be continued, specifically during the very dry months. The negative effect of grass on the growth of oaks may be attributed to their shading from the dense grass biomass. It can be concluded that control of competitive vegetation, especially of grasses, is crucial for Quercus ithaburensis ssp. macrolepis regeneration by natural (from acorns) or artificial (with up to one-year-old seedlings) methods. This control is necessary at least in the first year after establishment, when seedling height is less than that of the competitive vegetation. If the latter can not be removed by some ways (e.g. controlled grazing), then it is safer to use taller oak seedlings of an older age in the reforestation projects.

KEYWORDS: valonia oak, grass, clover, competition, companion plants.

\section{INTRODUCTION}

Quercus ithaburensis Decaisne ssp. macrolepis Kotschy is a typical mediterranean species that grows from Italy to Israel and Palestine (Quezel and Bonin, 1980; Athanasiadis, 1986; Quezel and Barbero, 1985; Tutin et al., 1993). In Greece, it is found from the north- east part of the country to the island of Crete, in the south (Pantera and Papanastasis, 2003; Athanasiadis, 1986). It mostly prefers warm areas where it forms dense forest stands. There were extensive Quercus ithaburensis ssp. macrolepis forests in the past (Tsitsas, 1978; Grispos, 1936) but only a few remain today due to illegal cuttings, wildfires, and overgrazing (Schultz et al., 1987). It has been widely used in the past for dye production extracted from its acorn cups as well as for fodder for its acorns (Grispos, 1936). Nowadays only its acorns are used for feed to livestock whereas its low quality wood is generally used only for firewood (Schultz et al., 1987).

In the past few years, there has been a growing interest for the species to be included in reforestation as well as in research projects (Radoglou, 1996; Tsakaldimi et al., 2000; Fotelli et al., 2000). On the other hand, there is extensive information on regeneration of oak species and the 
factors that are affecting it (Baker et al., 1981; Gordon et al., 1991; Lorimer et al., 1994; Muick, 1997; McCreary and Tecklin, 1997). The existing knowledge on Quercus ithaburensis ssp. macrolepis establishment and regeneration is circumstantial and no scientifically documented information is available. More important, there is no information on the factors that affect species establishment and growth.

Quercus ithaburensis ssp. macrolepis forms typical silvopastoral systems in several parts of Greece, which are mainly used for grazing by livestock, especially sheep. Pantera and Papanastasis (2003) documented regeneration problems mainly caused by overgrazing. Does understory vegetation contribute to this regeneration problem? In general, companion herbaceous plants greatly influence the establishment and growth of woody species. As Gordon et al. (1989) mention, the spatial arrangement and size of adjacent plants has partially explained the variability in growth and seed production of target plants in experimental and model systems (Weiner, 1982; Heywood and Levin, 1986; Firbank and Watkinson, 1987). It is logical to assume that species identity within a neighborhood will affect the intensity of interspecific competition. The interplantation of species with different morphology as well rooting and growth patterns has been hypothesized to permit species coexistence (McDicken and Vergara, 1990; Sharow and Fletcher, 1994; Koukoura et al., 1999). This paper represents a first attempt to investigate the effects of the companion plants on $Q$. ithaburensis ssp. macrolepis. Specifically, water availability and field performance of growth as influenced by the presence of companion herbaceous plants was investigated so that guidelines are developed for proper regeneration and management of the species.

\section{MATERIALS AND METHODS}

The research was conducted at the State Forest Nursery of Amygdaleza, on the foothill of Parnitha mountain, near Athens, Greece $\left(38^{\circ} 8^{\prime} \mathrm{N}\right.$ and $\left.23^{\circ} 45^{\prime} \mathrm{E}\right)$, at an altitude of $330 \mathrm{~m}$. The climate is Mediterranean with a mean annual precipitation of about $470 \mathrm{~mm}$. Based on the meteorological data from the nearest to the study site meteorological station (Tatoi), the dry season for the study year started in the first 10 days of May and ended in the first 10 days of October.

Quercus ithaburensis ssp. macrolepis acorns were collected from various areas of the prefecture of Attica. The quality of seeds was tested visually and by the water-bath method described by Bonner and Vozzo (1987). The acorns were first pre-germinated and then planted in plastic containers of 60 $\mathrm{cm}$ diameter, $80-90 \mathrm{~cm}$ height, and approximately $283.5 \mathrm{~L}$ volume. Four oak plants were randomly selected and planted in each container. The volume (liters) of the plastic containers was considered adequate to eliminate any possible competition between the species for space.

The companion species were the annual grass Bromus sterilis and a mixture of two perennial clovers Trifolium repens and $T$. fragiferum (20:1). Bromus sterilis has a relatively dense root biomass (Papanastasis and Karagiannakidou-Papadimitriou, 1983) and is widely distributed in the Quercus ithaburensis ssp. macrolepis environment. Trifolium species are also found in the oak's environment but restricted in the better sites (with deep soil). Trifolium seedlings initially develop an extensively branched tap root system and, subsequently, adventitious roots with numerous lateral branches arise from the nodes of stolons. Most of the Trifolium roots are found in the upper $20 \mathrm{~cm}$ of soil (Caradus, 1990; Frame et al., 1998). Seeds of the companion plants were collected in 1996 and were seeded directly to the plastic containers at a mean density of 350 plants $\mathrm{m}^{-2}$ or about 100 plants/container. This density was chosen after field trials in areas where Quercus ithaburensis ssp. macrolepis was found. Gordon et al. (1989) used similar densities based on a report of Heady (1958) for California annual grasslands.

Overall, 30 plastic containers were used. Ten of them were planted with only Quercus ithaburensis ssp. macrolepis, ten with Q. ithaburensis ssp. macrolepis and grass, and ten with Q. ithaburensis ssp. macrolepis and clovers. Any other plants growing in the containers were removed manually during the experiment.

Water potential measurements were made by the Dew Point Method using a Wescor Microvoltometer and an L-51 Leaf Hygrometer/Psychrometer. The method was chosen based on the relevant literature (Campbell and Campbell, 1974; Brown and Tanner, 1981; Savage et al., 1983) and the fact that it was necessary at the end of the experiment to measure the amount of leaves in each oak seedling. The measurements were initiated in mid-April 1997, repeated every 20 days and terminated in the first week of September 1997. Altogether, seven midday water potential 
measurements were taken of the oak plants over the whole season. Measurements were made on one leaf per plant (Brown and Tanner 1981), facing the sun (Baker et al., 1981).

Plants were watered to field capacity weekly. Before sampling only half of the plants were watered. All plants were well watered after the termination of each measurement.

All the plants were harvested at the end of the experiment and were carried in plastic bags to the laboratory where they were oven dried at $70^{\circ} \mathrm{C}$. Before drying, oak plants were separated into stems, leaves, and roots. For each plant the following parameters were recorded: i. total number of leaves and dry weight, and ii. stem and root length and dry weight.

For the water potential data, a two-way analysis of variance was applied within each date with planting combinations and water being the two factors. For the growth data, only the planting combinations were compared with an one-way analysis of variance since all plants received the same amount of water as regard the growth parameters. In both cases, the studentised range test of the means was applied after ANOVA (Anderson and McLean, 1974). On an overall basis, all the plants received the same amount of water so no discrimination, as to irrigation, was made on the growth parameters. All tests for significance were conducted at $p=0.05$

All the statistical analyses were performed by the SPSS $v .13$ software program.

\section{RESULTS}

\subsection{Water potential}

Figure 1 shows that the highest water potential values were found for the watered Quercus ithaburensis ssp. macrolepis plants whereas the lowest for the water-stressed plants, for all sampling dates. No statistical differences were found between the watered plants in all sampling dates. There were no statistical differences in the water potential of the water-stressed plants, irrespectively of the treatment, for the May $24^{\text {th }}$, June $14^{\text {th }}$, August $16^{\text {th }}$ and September $6^{\text {th }}$ samplings. The water potential values were relatively low during the July $26^{\text {th }}$ sampling for the water-stressed plants. Similar low values were found by Tsakaldimi et al. (2000) and Fair and Breshears (2005) for water-stressed oak plants. Oaks growing with grass had higher water potential than those growing with clover. It should be noted that by that date the grass had already completed its life cycle. Furthermore, July was a very warm and dry month and the temperatures during the sampling date were the highest of all other dates and ranged from 18.8 to $33.4{ }^{\circ} \mathrm{C}$ (Tatoi M.S.).

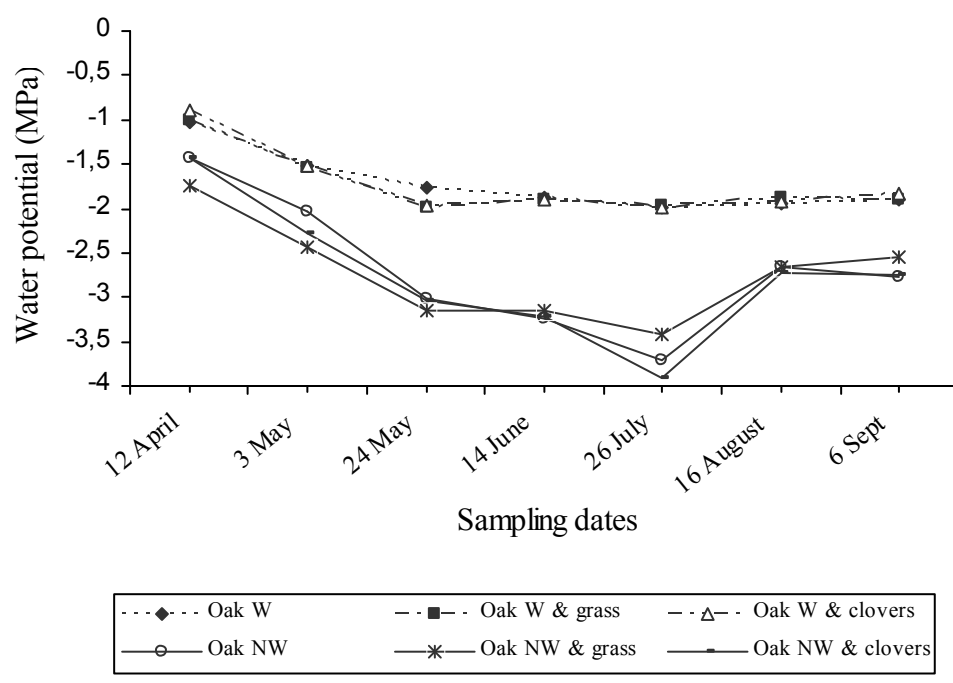

Figure 1. Midday water potential (MPa) in the sampling dates for the watered (dotted lines) and water-stressed plants (solid lines)

\subsection{Growth data}

The presence of grass negatively affected the growth of valonia oak as expressed by the leaf numbers and dry weight as well as the stem dry weight (Table 1). 
Table 1. Growth data of the oak seedlings

\begin{tabular}{lccc}
\hline Growth parameter & Only oak & Oak with grass & Oaks with clover \\
& & & \\
\hline Leaf Dry Weight (gr) & $1.71 \mathrm{a}^{1}$ & $0.72 \mathrm{~b}$ & $1.83 \mathrm{a}$ \\
Leaf Number & $23.70 \mathrm{a}$ & $15.19 \mathrm{~b}$ & $26.00 \mathrm{a}$ \\
Stem Dry Weight (gr) & $1.34 \mathrm{a}$ & $0.62 \mathrm{~b}$ & $1.74 \mathrm{a}$ \\
Stem Length (m) & $0.20 \mathrm{a}$ & $0.17 \mathrm{a}$ & $0.19 \mathrm{a}$ \\
Root Dry Weight (gr) & $4.94 \mathrm{a}$ & $3.67 \mathrm{a}$ & $6.92 \mathrm{~b}$ \\
Root Length (m) & $0.58 \mathrm{a}$ & $0.59 \mathrm{a}$ & $0.70 \mathrm{~b}$ \\
$\begin{array}{l}\text { Root dry weight/Stem } \\
\text { dry weight (R/S) }\end{array}$ & $6.49 \mathrm{a}$ & $6.05 \mathrm{ab}$ & $4.05 \mathrm{~b}$
\end{tabular}

'Values followed by the same letter within each row are not different at the 0.05 level of significance.

The presence of clover favored root growth of the oaks since root dry weight and length were found higher as compared with the other two growing combinations (Table 1). The positive effect of nitrogen fixing species on companion plants' growth have been documented in previous studies (Heichel and Henjum, 1991; Pantera and Pope, 1993) and may be partly attributed to higher amounts of soil available nitrogen. The growing combinations did not affect oaks' stem length, at least for the study period.

One of the most common drought adaptations of oaks, additionally to the deep extensive root system, is the high root-to-shoot ratio (Abrams, 1990; Pallardy and Rhoads, 1993). This ratio (R/S) was found lower for the oaks that grew with the clover (Table 1). There are no previous data on the species root-to-shoot ratio but comparing our data with those reported by Drunasky and Struve (2005), for Quercus macrocarpa and Q. prinus, it appears that the presence of clover favors oak performance.

Table 2. Growth data of the companion plants

\begin{tabular}{lccc}
\hline Companion plant & Height $(\mathbf{m})$ & Weight $\left(\mathbf{g r ~}^{-2}\right)$ & Density (\# plants $\mathbf{~ m}^{-2}$ ) \\
\hline Grass & 0,38 & 321,3 & 338,3 \\
Clover & 0,12 & 373,5 & - \\
\hline
\end{tabular}

Companion plants had high biomass (Table 2), and specifically, grasses were higher than the mean height of oaks (Table 1). Furthermore, based on data by Koukoura and Menke (1995) for Quercus douglasii, the density of the grasses may be considered as high. The clover had established numerous stolons by harvest time, prohibiting an accurate determination of its density.

\section{DISCUSSION}

The results suggest a different effect on the water potential of the oak seedlings depending on the companion plant species and the time of the year. Gordon et al. (1989), who also emphasize the importance of the companion plant and, specifically, its rooting system, report similar results. The same authors found greater water consumption in containers of oaks (Q. douglasii) with Bromus diandrus as compared with those of oaks with Erodium botrys. The grass had higher number of roots and biomass throughout the container and, consequently, a greater water consumption compared with the other species. Koukoura and Menke (1995) found that the negative effect of companion plants on $Q$. douglasii survival and establishment was relieved only for a plant density of $50 \mathrm{~m}^{-2}$ whereas 199 plants $\mathrm{m}^{-2}$ was considered a high density with pronounced negative results. Another effect of the grasses to its companion plants is the shadow cast by the grass onto the soil. As Muick (1997) mentions, shadowing the soil may result in lower soil water evaporation.

The presence of a companion plant that has completed its life cycle by the end of spring may positively influence the water status of oaks during the summer months due to shading and lower soil water evaporation. On the contrary, when the companion plants continue their life cycle in the summer, the negative effect may be continued, specifically during the very dry months. The clovers used in the present study, being perennial species, continued their growth activities during the summer resulting to higher water demands. Their affect was critical and obvious only when available 
water was very low due to the climatic conditions. However, the oaks growing with clover performed better indicating a greater drought tolerance. It seems that the presence of the nitrogen fixing plants positively affected oak growth by increasing the available nitrogen. Kim et al. (1996) found that the removal of the dominant stand resulted to increased dry weight and $\mathrm{N}$ absorption by Q. rubra plants. These positive effects were partly attributed to the greater quantity of available soil nitrogen. However, further research on the subject is needed before more concrete conclusions can be drawn.

The negative effect of grass on the growth of oaks may be attributed to their shading from the dense grass biomass. Shade grown seedlings in combination with water stress appear to have a lower ability for osmotic adjustment and, subsequently, a lower efficiency in developing drought tolerance mechanisms (Pardos et al., 2005). Similarly, Čater and Batič (2006), indicate the combining effect of ground water table and light conditions on the photosynthetic yield and, subsequently, the survival of Quercus robur seedlings. Baker et al. (1981) report that Quercus douglasii growth period differs according to the area. Shoot elongation begins on February or March and continues for 2-3 months. Leaf growth starts in certain areas at the same time with shoot elongation whereas in others right after shoot elongation decreases. Furthermore, Noitsakis and Tsiouvaras (1990) report that Q. coccifera plants responded to drought by decreasing their leaf area growth rate. This decrease in leaf area growth rate is connected with water stress, and appears to be the result of decreased photosynthesis and photosynthates partitioning (Chartzoulakis et al., 1993). The same authors found that shaded leaves of Actinidia sinensis had lower weight than those exposed to light. Similar results were found by Sung et al. (1998) for Q. rubra and Q. alba seedlings. Additionally, Meletiou-Christou et al. (1993) found that sunleaves of $Q$. coccifera had more starch, total N, proteins, total lipids, and energy content of storage substances as compared with the shade leaves. It may be assumed that the oak seedlings in the present study responded to shade and to decreased soil moisture by decreased growth. Similar results and root/shoot ratios have been found by Tsakaldimi et al. (2000) for plants to which medium water stress were applied. Furthemore, Gordon et al. (1989) found that, due to induced soil drying rates by the companion plants, control seedlings had twice as long roots to those growing in a high density grass treatment. It appears that the positive effect of the grass through shading during the summer was inadequate to override its negative affect on oaks' growth due to water stress during the spring, a period with the highest water demands for physiological processes. Competition with the understory herbs for soil water should be regarded as one of the main factors controlling recruitment of Mediterranean oaks (Esteso-Martínez et al., 2006). For that purpose, control of the competitive vegetation may decrease the negative results of their presence and increase seedlings' survival.

\section{CONCLUSION}

It can be concluded that control of competitive vegetation, especially of grasses, is crucial for Quercus ithaburensis ssp. macrolepis regeneration by natural (from acorns) or artificial (with up to one-year-old seedlings) methods. This control is necessary at least in the first year after establishment, when seedling height is less than that of the competitive vegetation. If the latter can not be removed by some ways (e.g. controlled grazing), then it is safer to use taller oak seedlings of an older age in the reforestation projects.

\section{REFERENCES}

Abrams M.D., (1990) Adaptation and responses to drought in Quercus species of North America, Tree Physiology, 7, 227-238.

Anderson V.L. and McLean R.A., (1974) Design of experiments, a realistic approach, Pub. Marcel Dekker INC, $418 \mathrm{p}$.

Athanasiadis N., (1986) Forest Botany (Trees and bushes of the greek forests), Part II, Pub. By Giahoudis - Giapoudis, Thessaloniki, 309 p.

Baker G., Rundel P. and Parsons D., (1981) Ecological Relationships of Quercus douglasii (Fagaceae) in the foothill zone of Sequoia National Park, California. Madrono, 28(1), 1-12.

Bonner F.T. and Vozzo J.A., (1987) Seed biology and technology of Quercus, Gen. Tech. Rep. SO-66, New Orleans, LA: U.S.D.A. Forest Service, Southern Forest Experiment Station; 21p. 
Brown P.W. and Tanner C.B., (1981) Alfalfa water potential measurement: A Comparison of the pressure chamber and leaf dew-point hygrometers, Crop Science, 21(4), 240-244.

Campbell G.S. and Campbell M.D. (1974) Evaluation of a thermocouple hygrometer for measuring leaf water potential In Situ, Agronomy Journal, 66, 24-27.

Caradus J.R., (1990) The structure and function of white clover root systems, Advances in Agronomy, 43, 1-46.

Čater M. and Batič F., (2006) Groundwater and light conditions as factors in the survival of pedunculate oak (Quercus robur L.) seedlings, European Journal of Forest Research, 125, 419-426.

Chartzoulakis K., Therios I. and Noitsakis B. (1993) Effects of shading on gas exchange, specific leaf weight and chlorophyll content in four kiwifruit cultivars under field conditions, Journal of Horticultural Science, 68(4), 605-611.

Drunasky N. and Struve D.K., (2005) Quercus macrocarpa and Q. prinus physiological and morphological responses to drought stress and their potential for urban forestry, Urban Forestry and Urban Greening, 4, 13-22.

Esteso-Martínez J., Camarero J.J. and Gil-Pelegrín E. (2006) Competitive effects of herbs on Quercus faginea seedlings inferred from vulnerability curves and spatial-pattern analyses in a Mediterranean stand (Iberian Sy stem, northeast Spain), Ecoscience, 13(3), 378-387.

Fair J.M. and Breshears D.D., (2005) Drought stress and fluctuating asymmetry in Quercus undulata leaves: confounding effects of absolute and relative amounts of stress? Journal of Arid Environments, 62, 235-249.

Firbank L.G. and Watkinson A.R., (1987) On the analysis of competition at the level of the individual plant, Oecologia 71, 308-317.

Fotelli M., Radoglou K. and Constantinidou H., (2000) Water stress responses of seedlings of four Mediterranean oak species, Tree Physiology, 20, 1065-1075.

Frame J., Charlton J.F.L. and Laidlaw A.S., (1998) Temperate forage legumes, CAB International.

Gordon D., Rice K. and Welker J., (1991) Soil Water effects on blue oak seedling establishment, Proceedings of the symposium on oak woodlands and hardwood rangeland management, U.S.D.A. Pac. S.R.S. General tecnhical report PSW-126.

Gordon D., Welker J., Menke J. and Rice K., (1989) Competition for Soil Water Between Annual Plants and Blue Oak (Quercus douglasii) Seedlings, Oecologia, 79, 533-541.

Grispos P., (1936) The acorns' extracts forest industry, Forest Life, 44-45, 157-160.

Heady H.F., (1958) Vegetational changes in the California annual type, Ecology, 39, 402-416.

Heichel G.H. and Henjum K.I., (1991) Dinitrogen fixation, nitrogen transfer, and productivity of foragegrass communities, Crop Science, 31, 202-208.

Heywood J.S. and Levin D.A., (1986) Interactions between seed source, planting arrangement, and soil treatment in determining plant size and root allocation in Phlox drummondii, Oecologia, 68, 285-290.

Kim C., Sharik T.L., Jurgensen M.F., Dickson R.E. and Buckley D.S., (1996) Effects of nitrogen availability on northern red oak seedling growth in oak and pine stands in Northern Lower Michigan, Canadian Journal of Forest Research, 26, 1103-1111.

Koukoura Z. and Menke J., (1995) Competition for soil water between perennial bunch-grass (Elymus glaucus B.B.) and blue oak seedlings (Quercus douglasii H.\&A.), Agroforestry Systems, 32, 225-235.

Koukoura Z., Vrahnakis M. and Karatassiou M., (1999) Effect of Dactylis glomerata and Festuca ovina on Pinus brutia seedling survival, In Grasslands and woody plants in Europe, Eds. V. Papanastasis, J. Frame and A. Nastis, Proceedings of the International Occasional Symposium of the European Grassland Federation, Thessaloniki, Greece.

Lorimer C.G., Chapman J.W. and Lambert W.D., (1994) Tall understorey vegetation as a factor in the poor development of oak seedlings beneath mature stands, Journal of Ecology, 82, 227-237.

McDicken K. and Vergara N., (1990) Agroforestry: Classification and management, J. Wiley \& Sons, 382 p.

McCreary D. and Tecklin J., (1997) Effects of seedling protectors and weed control on blue oak growth and survival, Proceedings of a symposium on oak woodlands: Ecology, management, and urban interface issues, USDA Forest Service, PSW-GTR-160, 243-250.

Meletiou-Christou M.S., Rhizopoulou S. and Diamantoglou S., (1993) Seasonal changes of carbohydrates, lipids, and nitrogen content in sun and shade leaves from four mediterranean evergreen schlerophylls, Environmental and Experimental Botany, 34(2), 129-141 
Muick P., (1997) Effects of shade and clipping on coast live and blue oak seedling mortality and growth in California annual grasslands, Proceedings of a symposium on oak woodlands: Ecology, management, and urban interface issues, USDA Forest Service, PSW-GTR-160, 243-250.

Noitsakis B. and Tsiouvaras C., (1990) Seasonal changes in components of leaf water potential and leaf area growth rate in kermes oak, Acta CEcologica, 11(3), 419-427.

Pallardy S.G. and Rhoads J.L., (1993) Morphological adaptations to drought in seedlings of decidous angiosperms, Canadian Journal of Forest Research, 23, 1766-1774.

Pantera A. and Pope P.E., (1993) Growth and nitrogen status of Juglans nigra and Fraxinus pennsylvanica interplanted with Robinia pseudoacacia, School of Forestry Report 1993, II(1), Auburn University, 55-62.

Pantera A. and Papanastasis V.P., (2003) Valonia oak (Quercus ithaburensis Decaisne subsp. macrolepis (Kotschy) Hedge \& Yalt.) in Greece, Geotechnical Scientific Subjects, 14(1), 33-44.

Papanastasis V. and Karagiannakidou-Papadimitriou K., (1983) The most important grasses of natural grasslands, Publication of the Greek Agricultural Ministry, 185p.

Pardos M., Jiménez M.D., Aranda I., Puértolas J. and Pardos J.A., (2005) Water relations of cork oak (Quercus suber L.) seedlings in response to shading and moderate drought, Annals of Forest Science, 62(5), 377-384.

Quezel P. and Barbero M., (1985) Carte de la végétation potentielle de la région méditerranéenne, Feuille $N^{\circ}$ 1: Méditerranée Orientale. Eds C.N.R.S. Paris, 69p.

Quezel P. and Bonin G., (1980) Les forêts feuillues du pourtour méditerranéen, Constitution, écologie, situation actuelle, perspectives, Revue For. Fr. XXXII(3), 253-268.

Radoglou K., (1996) Envrironmental control of $\mathrm{CO}_{2}$ assimilation rates and stomatal conductance in five oak species growing under field conditions in Greece, Annales des Sciences Forestières, 53, 269278.

Savage M.J., Wiebe H.H. and Cass A., (1983) In Situ field measurement of leaf water potential using thermocouple psychrometers, Plant Physiology, 73, 609-613.

Schultz A., Papanastasis V., Katelman T, Tsiouvaras C., Kandrelis S., Nastis A., (1987) Agroforestry in Greece, Working document, Aristotle University of Greece.

SPSS Software for statistical analyses. V. 13.0 for Windows. SPSS, $11^{\text {th }}$ Floor, Chicago, IL 60606-6307, USA.

Sung S.S., Kormanik P.P. and Zarnoch S.J. (1998) Photosynthesis and biomass allocation in oak seedlings grown under shade, Proceedings of the ninth biennial southern silvicultural reasearch conference, USDA Forest Service, June 1998

Tsakaldimi M., Ganatsas P., Gounaris N., Zagas T., Tsitsoni T. and Chatzistathis A., (2000) Water potential effect on the quality of annual seedlings, Proceedings of the $9^{\text {th }}$ Hellenic forestry association conference, Kozani 17-20 October 200, 170-179.

Tsitsas S., (1978) The wildtrees of the mountain and the hills, history - mythology - laography - poetry physiolatry, 300 p. Book, Athens.

Tutin T.G., Burges N.A., Chater A.O., Edmondson J.R., Valentine D.H., Walters S.M. and Webb D.A., (1993) Flora Europaea, Vol. 1, Second Edition, Cambridge University Press, Cambridge, 581 p.

Weiner J., (1982) A neighborhood model of annual plant interference, Ecology, 63, 1237-1241. 